\title{
Effect of lactic acid bacteria on changes of aflatoxin levels during kimchi fermentation
}

\author{
Seon-Hwa Cheon, Su-ji Kim, Sang-il Lee, Youngbae Chung, Sung Hyun Kim, \\ Jungeun Cho, Hye-Young Seo* \\ World Institute of Kimchi, Gwangju 61755, Korea
}

\section{젖산균이 김치 발효 중 아플라톡신 함량 변화에 미치는 영향}

\author{
천선화·김수지·이상일·정영배·김성현·조정은·서혜영* \\ 세계김치연구소
}

\begin{abstract}
Red pepper powder sensitive to aflatoxins contamination is major ingredients of kimchi. This study was conducted to investigate the effect of lactic acid bacteria (LAB) on the changes in aflatoxin levels during kimchi fermentation. Baechu kimchi was contaminated with aflatoxins $\left(B_{1}, B_{2}, G_{1}\right.$, and $G_{2}$ ) and inoculated with LAB (Lactobacillus plantarum and Leuconostoc mesenteroides), and the following characteristics were investigated for 8 weeks: pH, titratable acidity, salinity, microbial properties, and aflatoxin levels. The $\mathrm{pH}$ decreased rapidly during storage, and the titratable acidity was increased. The salinity of the samples was shown to increase from 2.30 to $2.40 \%$. The total number of aerobic bacteria and lactic acid bacteria in kimchi inoculated with LAB was significantly higher than that of the others. Yeast and molds were detected at approximately $1 \sim 3 \mathrm{log} \mathrm{CFU} / \mathrm{g}$ during storage. Coliforms were detected in the control after 4 weeks, whereas in other samples they were not detected until after 2 weeks. The aflatoxin levels reduced during kimchi fermentation. The average reduction rate of aflatoxin levels during kimchi fermentation was $\mathbf{8 . 3 9 \%}$, but in kimchi inoculated with Lac. plantarum and Leu. mesenteroides, the rate were 25.16 $\%$ and $\mathbf{2 7 . 8 6} \%$, respectively. These results showed that aflatoxins can be removed by LAB during kimchi fermentation.
\end{abstract}

Key words : kimchi, aflatoxins, lactic acid bacteria, Lactobacillus plantarum, Leuconostoc mesenteroides

\section{서 론}

아플라톡신(aflatoxin)은 Aspergillus flavus, Aspergillus parasiticus 및 Aspergillus nomius 등 주로 Aspergillus section Flavi에 속하는 곰팡이가 생산하는 2차 대사산물로서 곡류, 두류, 견과류 등 농산물과 그 가공품에서 광범위하게 발견 되고 있다 $(1,2)$. 현재까지 알려진 아플라톡신은 약 20 여종 으로 그 중 아플라톡신 $\mathrm{B}_{1}, \mathrm{~B}_{2}, \mathrm{G}_{1}$ 및 $\mathrm{G}_{2}$ 가 가장 흔하게 발견되며 특히 아플라톡신 $\mathrm{B}_{1}$ 의 경우 가장 독성이 강력하

*Corresponding author. E-mail : hyseo@wikim.re.kr

Phone : 82-62-610-1731, Fax : 82-62-610-1850

Received 28 July 2015; Revised 7 October 2015; Accepted 12 October 2015.

Copyright (c) The Korean Society of Food Preservation. All rights reserved.
여 국제암연구소(international agency for research on cancer, IARC)에서 group 1(carcinogenic to humans)으로 분류하고 있다. 이러한 아플라톡신이 인체에 노출될 경우 발암성 및 최기형성, 간장독성 등을 유발하는 것으로 알려져 있다 (3-5).

아플라톡신은 주로 온도 $28 \sim 30^{\circ} \mathrm{C}$, 상대습도 $85 \%$ 조건의 고온다습한 열대나 아열대지방에서 잘 생성되며 온도 및 습도가 높은 장소에 장기간 저장되거나 수확에서 건조까지 저장기간이 길고 환기가 불충분할수록 잘 생성된다. 특히 땅콩, 쌀, 보리, 밀, 옥수수 등 탄수화물 함량이 높은 기질에 서 잘 생성되는 것으로 알려져 있다(6,7). 우리나라의 경우 곡류를 주식으로 하고 있고, 많은 농산물과 식품을 수입에 의존하고 있을 뿐 만 아니라 지속적인 환경오염과 지구 온난화로 인해 최근 아열대성 기후로 변화하고 있는 실정이 므로 농산물 및 그 가공품이 아플라톡신에 노출될 가능성이 
더욱 높아졌다(3). 특히 일본에서 한국산 수입식품에 대하 여 기존에 고춧가루, 피넛츠 등과 같이 아플라톡신 발생 원료에만 적용하던 명령검사를 김치, 고추장, 젓갈류 등 아플라톡신 발생 원료가 포함된 가공식품까지 대상을 확대 (2012년 4월부터)하여 국내에서도 곰팡이 독소에 대한 엄 격한 기준관리가 필요하게 되었다. 우리나라에서는 식품 및 농산물(곡류, 두류, 땅콩, 견과류 및 그 단순 가공품, 된장, 고추장, 고춧가루)에 대해 아플라톡신 $\mathrm{B}_{1}$ 을 $10 \mu \mathrm{g} / \mathrm{kg}$ 이하의 기준으로 설정하여 규제하여 관리하다가 2009년 3 월부터는 곡류, 두류, 땅콩, 견과류 및 그 단순가공품 뿐만 아니라 곡류가공품, 두류가공품, 장류 및 고춧가루에 대하 여도 총 아플라톡신 $\left(\mathrm{B}_{1}, \mathrm{~B}_{2}, \mathrm{G}_{1}, \mathrm{G}_{2}\right)$ 기준을 $15 \mathrm{\mu g} / \mathrm{kg}$ 이하로 강화시키고 관리 대상 식품의 범위는 향신료, 밀가루, 건조 과실 등으로 확대하여 관리하고 있다 $(8,9)$.

아플라톡신 관리 대상이 되는 고춧가루는 김치에 첨가되 는 주요 양념이며, 김치 외에도 고추장 및 젓갈류 등 발효식 품에 다양하게 이용되고 있는 중요한 향신료이다. 고춧가 루의 재래식 제조과정에는 고추를 수확 후 건조기나 태양 빛을 이용하여 건조할 때 살균과정이 없어 자연계에 널리 분포된 Aspergillus속의 곰팡이나 미생물의 오염 가능성이 높다. 우리나라 식생활은 고춧가루를 이용한 음식의 종류 가 많고 특히 무침류는 가열하지 않은 상태로 혼합 향신료 로 사용하여 직접 식용하기 때문에 아플라톡신에 오염된 고춧가루를 섭취하게 될 가능성이 있다(14,15). 국내에서도 고춧가루 및 고추장에서 아플라톡신 오염사례가 보고된 바 있으며(16-18), 외국에서도 고춧가루 및 칠리분말, 후추 등의 각종 향신료에서 오염사례가 보고되었다(19-23). 현재 까지 김치에 대한 아플라톡신 오염 사례는 보고된 바 없으 나, 고춧가루가 들어간 김치가 한국의 김치로 인식되는 상 황에서 아플라톡신으로부터 김치가 안전하다는 과학적 근 거를 마련할 필요가 있다.

김치는 한국의 가장 대표적인 발효식품으로 주원료인 배추는 한국인의 주 식이섬유 공급원의 역할과 각종 비타민 의 공급원으로 이용되며, 부재료인 고춧가루, 마늘, 양파, 부추, 생강, 젓갈 등은 김치의 발효에 관여하여 각종 항암 효과와 유산균 공급의 역할을 한다. 김치의 발효는 혐기적, 호염성의 젖산균에 의해 진행되며 발효과정을 통해 젖산균 은 유기산, bacteriocin 등의 물질을 생산하여 유해한 세균들 의 증식을 억제하고 김치에 독특한 향미를 부여한다. 일반 적으로 김치의 초기 발효에 관여하는 젖산균은 Leuconostoc mesenteroides로 알려져 있으며, 이는 초기 김치의 산 생성 을 주도하고 혐기적 조건을 유지하게 하여 호기성 세균의 성장을 억제하는 것으로 알려져 있다. 또한 발효 후기에는 Lactobacillus plantarum가 김치의 맛과 품질에 관여하는 것으로 알려져 있다(10-13). 최근에는 이러한 젖산균이 김 치 맛의 균일성을 유지하기 위하여 starter로서 산업적으로 널리 이용되고 있으며, 발효식품에서 젖산균 starter의 이용
은 부족한 젖산균을 보완해 줄 수 있을 뿐만 아니라 기능성 이 우수한 starter를 이용할 경우 김치의 기능성 증진효과를 기대할 수 있다(24). 특히 Lactobacillus속, Bifidobacterium 속, Lactococcus속, Leuconostoc속 등의 다양한 젖산균은 아플라톡신과 결합하여 아플라톡신 함량을 감소한다는 보 고가 있어(25-28) 김치 원료가 아플라톡신에 오염되었을 때 김치 발효 중 저감효과를 기대할 수 있을 것으로 생각된다.

본 연구에서는 김치 발효에 관여하는 주요 젖산균 중 Lac. plantarum과 Leu. mesenteroides를 starter로 선정하고 김치에 접종하여 초기 젖산균 수를 강화하고, 아플라톡신 을 오염시켜 저장기간 중 아플라톡신 오염 수준의 변화를 확인하여 젖산균에 의한 아플라톡신 감소 효과를 조사하고 자 하였다.

\section{재료 및 방법}

\section{재료 및 시약}

실험에 사용된 절임배추는 광주광역시 (주감칠배기 공장 에서 당일 제조한 것을 구입하여 사용하였으며 부재료인 무, 쪽파, 마늘, 생강(국내산)은 광주 서부농수산물도매시 장에서 구입하였다. 고춧가루(Yeongyang farmers, Yeongyang, Korea) 및 찹쌀가루(Cheonghwa food, Gwangju, Korea)는 인근 마트에서 구입하여 실험에 사용하였다. 김치제조에 사용한 아플라톡신 $\mathrm{B}_{1}, \mathrm{~B}_{2}, \mathrm{G}_{1}$, 및 $\mathrm{G}_{2}$ 표준품(Supelco Co., Bellefonte, PA, USA)은 분말형태의 제품을 구입하여 사용 하였으며, 기기분석에 사용한 아플라톡신 표준품은 $\mathrm{B}_{1}, \mathrm{~B}_{2}$, $\mathrm{G}_{1}$, 및 $\mathrm{G}_{2}$ 가 각각 $1,0.3,1$ 및 $0.3 \mu \mathrm{g} / \mathrm{mL}$ 농도로 혼합된 용액(Supelco Co., Bellefonte, PA, USA)을 구입하여 사용하 였다.

\section{젖산균 배양}

김치의 제조 시 첨가한 젖산균은 Lac. plantarum( $\mathrm{KCCM}$ 11322)과 Leu. mesenteroides(KCCM 11325)로 한국미생물 보존센터에서 균주를 분양받아 사용하였다. 분양받은 균주 는 MRS (Lactobacilli MRS agar, Difco Co., USA) 고체평판

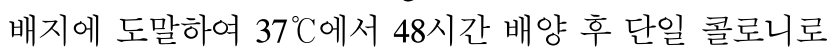
계대배양시켰다. 각 균주는 MRS(Lactobacilli MRS broth, Difco Co., Detroit, MI, USA) 액체배지에서 접종한 뒤 $37^{\circ} \mathrm{C}$ 에서 24시간 동안 배양하여 활성화시킨 후, $3,000 \mathrm{rpm}$ 에서 10 분간 원심분리하여 배지를 제거하였다. 배지 제거 후 생 성된 pellet은 멸균증류수로 3회 세척하여 김치 양념에 약 $7 \log \mathrm{CFU} / \mathrm{g}$ 수준으로 첨가하였다.

\section{김치 제조}

절임배추는 추대고를 자른 뒤 배추의 잎부분과 줄기부분 을 2 3 cm 크기로 절단하여 골고루 혼합하였다. 부재료인 
무와 마늘 생강을 믹서기를 이용하여 분쇄하였으며, 쪽파 는 $2 \mathrm{~cm}$ 크기로 절단하였다. 준비한 원부재료는 Table 1 과 같은 비율로 첨가하여 버무린 뒤 김치를 제조하였다. 제조 된 김치에 Lac. plantarum(LP)과 Leu. mesenteroides(LM)를 각각 시료별로 첨가하고, 이후 미리 제조한 아플라톡신 $(\mathrm{AFs})$ 표준용액을 첨가하여 아플라톡신 $\mathrm{B}_{1}, \mathrm{~B}_{2}, \mathrm{G}_{1}$, 및 $\mathrm{G}_{2}$ 의 농도가 각각 $10 \mu \mathrm{g} / \mathrm{kg}$ 이 되도록 김치에 오염시켰다. 제조된 김치는 $\mathrm{PE} \mathrm{bag}$ 에 담은 후 최대한 내부 공기를 탈기하여 실링기(NT 400, HANATO Co., Gimcheon, Korea)를 이용하 여 포장하였다. 제조된 시료는 대조구(A)와 아플라톡신 오 염구(B, AFs 오염구), 아플라톡신 오염 및 Lac. plantarum 접종구 $(\mathrm{C}, \mathrm{AFs}+\mathrm{LP})$, 아플라톡신 오염 및 Leu. mesenteroides 접종구 $(\mathrm{D}, \mathrm{AFs}+\mathrm{LM})$ 로 구분되며, 제조 직 후 $4^{\circ} \mathrm{C}$ 에 8 주 동안 저장하며 2주 간격으로 채취하여 품질 특성을 분석하였다.

Table 1. Ingredient compositions of kimchi

\begin{tabular}{lc}
\hline \multicolumn{1}{c}{ Ingredients } & Ratio $(\%, \mathrm{w} / \mathrm{w})$ \\
\hline Brined kimchi cabbage & 80 \\
Red pepper powder & 3 \\
Grinded radish & 3 \\
Grinded garic & 2.5 \\
Grinded ginger & 0.8 \\
Green onion & 2.5 \\
Salted anchovy sauce & 3 \\
Glutinous rice paste & 0.8 \\
Water & 4.4 \\
& Total \\
\hline
\end{tabular}

\section{$\mathrm{pH}$ 및 적정 산도}

$\mathrm{pH}$ 는 blender로 간 반죽상태의 시료에 $\mathrm{pH}$ electrode (ORION 3 STAR, Thermo scientific, Waltham, MA, USA)를 직접 넣어 측정하였다. 적정산도는 blender로 간 반죽상태 의 시료 약 $1 \mathrm{~g}$ 을 정확히 달아 적당히 희석 $(100 \mathrm{~mL})$ 하여 여과(Advantec No. 1)한 여과액 $20 \mathrm{~mL}$ 에 $0.01 \mathrm{~N} \mathrm{NaOH}$ 용액으로 $\mathrm{pH}$ 가 8.3이 될 때까지 적정하여 소비된 $0.01 \mathrm{~N}$ $\mathrm{NaOH}$ 용액 소비량을 구한 후 다음의 식에 따라 lactic $\operatorname{acid}(\%, w / v)$ 로 환산하였다.

$$
\text { 적정산도 }(\%, \mathrm{w} / \mathrm{v})=\frac{(A-B) \times 0.0009 \times f \times D}{S} \times 100
$$

여기에서 A: 본 시험에 소비된 $0.01 \mathrm{~N} \mathrm{NaOH}$ 용액의 $\mathrm{mL}$ 수, $\mathrm{B}$ : 바탕시험에 소비된 $0.01 \mathrm{~N} \mathrm{NaOH}$ 용액의 $\mathrm{mL}$ 수, $\mathrm{f}: 0.01 \mathrm{~N} \mathrm{NaOH}$ 용액의 역가, $\mathrm{D}$ : 희석배수, $\mathrm{S}$ : 시료채취량 $(\mathrm{g})$ 이다.

\section{염 도}

염도는 blender로 간 반죽(paste)상태의 시료 약 $1 \mathrm{~g}$ 을 정확히 달아 100 배 희석하여 여과한(Advantec No. 1) 여과 액을 $10 \mathrm{~mL}$ 를 취하여, $2 \%$ potassium chromate $1 \mathrm{~mL}$ 를 넣어 $0.02 \mathrm{~N} \mathrm{AgNO}_{3}$ 용액으로 적정하여 다음의 식을 이용하여 계산하였다.

$$
\text { 염도 }(\%, \mathrm{w} / \mathrm{v})=\frac{(A-B) \times 0.00117 \times f \times D}{S} \times 100
$$

여기에서 $\mathrm{A}$ : 본 시험에 소비된 $0.02 \mathrm{~N} \mathrm{AgNO}_{3}$ 용액의 $\mathrm{mL}$ 수, $\mathrm{B}$ : 바탕시험에 소비된 $0.02 \mathrm{~N} \mathrm{AgNO}_{3}$ 용액의 $\mathrm{mL}$ 수, f: $0.02 \mathrm{~N} \mathrm{AgNO}_{3}$ 용액의 역가, $\mathrm{D}$ : 희석배수, $\mathrm{S}$ : 시료채취량 (g)이다.

\section{미생물학적 특성}

마쇄한 김치 시료 $10 \mathrm{~g}$ 을 멸균 $\mathrm{bag}$ 에 넣고 멸균된 $0.85 \%$ $\mathrm{NaCl} 90 \mathrm{~mL}$ 를 첨가하여 1 분 동안 bag $\operatorname{mixer}(400 \mathrm{vw}$, Interscience Co., St Nom., France)에서 균질화하였다. 이를 10 진 희석법으로 희석한 뒤 각각의 배지에 접종하였다. 일 반세균수는 PCA(plate count agar, Difco Co., Detroit, MI, USA)배지를 사용하여 단계별로 희석한 시료를 접종한 후 pour plate method로 $30^{\circ} \mathrm{C}$ 에서 48 시간 배양하여 계수하였다. 젖산균수는 MRS (Lactobacilli MRS agar, Difco Co., Franklin Lakes, NJ, USA)배지에 25 ppm의 BCP(bromocresol purple) 지시약을 넣어 제조한 뒤 단계별로 희석한 시료를 접종하여 pouring culture method로 $30^{\circ} \mathrm{C}$ 에서 48 시간 배양하 고 총 colony와 yellow 발색 반응을 나타낸 colony를 계수하 였다. 효모 및 곰팡이 균수는 PDA(potato dextrose agar, Difco Co., Detroit, MI, USA)배지에 $10 \%$ tartaric acid를 첨가 하여 제조한 뒤 멸균하여 단계별로 희석한 시료를 접종한 다음 spread plate method로 $25^{\circ} \mathrm{C}$ 에서 72 시간 배양 후 계수하 였다. 대장균 및 대장균군은 대장균 및 대장균군 계수용 petri film(E. coli/coliform count plate, 3M Co., MN, USA)에 시료 희석액을 접종한 뒤 $30^{\circ} \mathrm{C}$ 에서 48 시간 배양하였다. Coliform은 생성된 붉은 집락 중 주위에 기포를 형성하고 있는 colony를 계수하였고, 대장균은 생성된 파란 집락 중 주위에 기포를 형성하고 있는 colony를 계수하였다.

\section{아플라톡신 생성균}

김치 제조 시 사용되는 부재료 중 아플라톡신 생성균으 로 알려진 $A$ flaus와 $A$ parasiticus의 존재 유무를 확인하기 위해 아플라톡신 생성균 확인 실험을 실시하였다. 시료 40 $\mathrm{g}$ 을 $0.1 \%$ 펩톤수 $200 \mathrm{~mL}$ 에 넣고 30 분간 혼합한 뒤 $0.1 \%$ 펩톤수로 $1: 10,1: 20,1: 40$ 의 비율로 희석하였다. 희석액은 chloramphenicol selective supplement(Oxoid Ltd., Basingstoke hampshire, UK)를 넣어 미리 제조한 AFPA base(Oxoid Ltd., 
Basingstoke hampshire, UK) 배지에 접종 후 도말하여 $30^{\circ} \mathrm{C}$ 에서 42시간 배양하였다. Plate 뒷면이 노란색/오렌지색인 모든 균수를 계측하여 검출될 경우 양성, 불검출될 경우 음성으로 판정하였다.

\section{총 아플라톡신 함량}

비커에 균질화 한 시료 약 $25 \mathrm{~g}$ 을 채취하여 methanol (Fisher scientific Co., PA, USA) $100 \mathrm{~mL}$ 를 가하고 초음파추 출기(Power sonic 520, HWASHIN, Seoul, Korea)로 5분간 균질화한 후 이를 여과지(Watman No. 1)로 여과하였다. 여액 $10 \mathrm{~mL}$ 를 $100 \mathrm{~mL}$ 플라스크에 취하고 $1 \%$ Tween 20 용액(Sigma chemical Co., MO, USA) $30 \mathrm{~mL}$ 를 가하여 혼합 한 다음 유리섬유여과지(Whatman, Maidstone, Kent, UK)로 여과한 것을 추출액으로 하였다. 추출액 $20 \mathrm{~mL}$ 를 immunoaffinity column(AflaTest, Vicam Co., MA, USA)에 주입하여 초당 1 2방울의 속도로 통과시킨 후 증류수 10 $\mathrm{mL}$ 로 column을 세척하고 acetonitrile (J.T.Baker, PA, USA) $3 \mathrm{~mL}$ 로 용출시켰다. 용출액을 질소농축기(HV-300, LABOGENE, Seoul, Korea)에서 $50^{\circ} \mathrm{C}$ 로 건조시키고 잔류물 에 trifluoroacetic acid(Junsei chemical, Tokyo, Japan) 0.2 $\mathrm{mL}$ 를 가하여 암소에서 15 분간 방치시킨 후 acetonitrile과 water(20:80, v/v) 혼합용액 $0.8 \mathrm{~mL}$ 를 가하여 혼합하고 0.2 $\mu \mathrm{m}$ membrane filter로 여과한 것을 시험용액으로 하였다. u-HPLC/FLD(Lachrom ultra, Hitachi, Tokyo, Japan) 기기분 석 조건은 Table 2 와 같으며, 총 아플라톡신의 함량은 다음 의 식에 따라 산출하였다.

총 아플라톡신의 함량 $(\mu \mathrm{g} / \mathrm{kg})=$

$\left(\mathrm{C}_{\mathrm{AFB} 1}+\mathrm{C}_{\mathrm{AFB} 2}+\mathrm{C}_{\mathrm{AFG} 1}+\mathrm{C}_{\mathrm{AFG} 2}\right) \times \mathrm{V} / \mathrm{S} \times \mathrm{D}$

$\mathrm{C}_{\mathrm{AFB} 1}$ : 검량선에서 구한 아플라톡신 $\mathrm{B}_{1}$ 의 농도 $(\mathrm{ng} / \mathrm{mL})$

$\mathrm{C}_{\mathrm{AFB} 2}$ : 검량선에서 구한 아플라톡신 $\mathrm{B}_{2}$ 의 농도 $(\mathrm{ng} / \mathrm{mL})$

$\mathrm{C}_{\mathrm{AFG} 1}$ : 검량선에서 구한 아플라톡신 $\mathrm{G}_{1}$ 의 농도 $(\mathrm{ng} / \mathrm{mL})$

$\mathrm{C}_{\mathrm{AFG} 2}$ : 검량선에서 구한 아플라톡신 $\mathrm{G}_{2}$ 의 농도 $(\mathrm{ng} / \mathrm{mL})$

$\mathrm{V}$ : 시험용액의 최종부피 $(\mathrm{mL})$

$\mathrm{S}$ : 시료 채취량 $(\mathrm{g})$

$\mathrm{D}$ : 시험용액의 희석배수

Table 2. Operating conditions of aflatoxins by u-HPLC/FLD

\begin{tabular}{lc}
\hline \multicolumn{1}{c}{ Instrument } & Hitachi, Lachrom Ultra \\
\hline Detector & 2485u-Fluorescence Detector \\
Column & LaChromUltra $(2.0 \mathrm{~mm} \times 50 \mathrm{~mm}, 2 \mu \mathrm{m})$ \\
Mobile phase & Acetonitrile:DW $=18: 82$ (isocratic) \\
Flow rate (mL/min) & 0.6 \\
Column temp. & $40^{\circ} \mathrm{C}$ \\
Injection volume & $5 \mu \mathrm{L}$ \\
Wavelength $(\mathrm{Ex} / \mathrm{Em}, \mathrm{nm})$ & $360 / 450$ \\
\hline
\end{tabular}

\section{통계분석}

실험결과는 IBM SPSS Statistics(19.0, IBM Corp., Armonk, NY, USA)를 이용하여 결과값에 대해 ANOVA 검정을 실시하여 유의적인 경우 $(\mathrm{p}<0.05)$, Duncan's multiple range test로 사후검정하였다.

\section{결과 및 고찰}

\section{$\mathrm{pH}$ 및 적정 산도}

김치는 숙성 기간 중 각종 효소와 미생물에 의해 생성된 유기산이 김치 특유의 신선한 맛을 부여하는 것으로 알려져 있다. 김치에서 생성된 유기산은 김치의 $\mathrm{pH}$ 를 감소시키는 반면 산도는 증가시켜 김치의 숙성정도를 짐작할 수 있는 중요한 지표라 할 수 있으며, 이를 통해 젓산균의 생육이나 김치의 발효도를 예상 할 수 있다(29).

아플라톡신 오염 및 젖산균 첨가를 실시한 김치의 제조 직 후 $\mathrm{pH}$ 는 5.33 5.50으로 나타났다(Table 3). $\mathrm{pH}$ 는 저장기 간이 증가할수록 점차 감소하여 저장 4주차에 모든 시료에 서 가장 급격한 변화를 나타내었다. 대조구의 경우 저장 직 후 $\mathrm{pH}$ 5.50로 가장 높은 $\mathrm{pH}$ 를 나타냈으나 저장기간이 경과할수록 다른 시험구와 비슷한 경향을 보였으며, 다른 시험구에서는 처리구간의 뚜렷한 차이가 나타나지 않았다. 모든 시료에서 저장 4주 이후 비슷한 수준의 $\mathrm{pH}$ 를 유지하다 저장 8주차에 4.06 4.14의 $\mathrm{pH}$ 를 나타냈다. 일반적으로 알려 진 김치의 적숙기 $\mathrm{pH}$ 는 4.2 정도이며, 이 수준 이상의 산도 가 높거나 $\mathrm{pH}$ 가 4.0 이하로 떨어진 경우에는 김치가 과숙되 어 군내가 나기 시작하고 신맛이 강해져 품질 및 기호도가 현저하게 감소한다고 보고되었다(30,31). 본 연구에서는 모 든 시료에서 저장 6 8주차에 최적숙기의 $\mathrm{pH}$ 에 도달한 것으 로 나타났다.

젓산균 첨가에 따라 김치의 초기 $\mathrm{pH}$ 는 대조구에 비해 젖산균 첨가구에서 더 낮게 나타났으며, 저장기간이 경과 할수록 $\mathrm{AFs}+\mathrm{LP}$ 에서 $\mathrm{AFs}+\mathrm{LM}$ 보다 더 빠른 감소속도를 나 타냈다. 이는 So 등(32)의 연구에서 저온성 스타터 첨가 김치 중 $\mathrm{pH}$ 감소속도가 Lactobacillus속을 첨가한 김치들이 Leuconostoc속을 첨가한 김치보다 더 빠르게 나타났다는 결과와 일치하였다. 김치의 숙성 과정 중 $\mathrm{pH}$ 의 감소 현상은 김치의 숙성이 진행됨에 따라 생성되는 여러 유기산들의 증가에 의한 것이며, 숙성 후기 $\mathrm{pH}$ 의 변화가 완만한 것은 발효가 진행됨에 따라 김치 내에 존재하는 유리 아미노산과 단백질, 무기 이온들의 완충 작용에 의해 기인되는 것으로 알려져 있다 $(33,34)$.

김치의 적숙기와 달리 과숙기에는 부패세균 및 잡균류가 증가하므로 신맛과 $\mathrm{pH}$ 값이 일치하지 않아 김치의 신맛을 나타내는 직접적인 지표로는 산도가 사용되므로(35), 본 연구에서는 포장용기에 따른 김치의 저장온도별 산도변화 
Table 3. Change in the $\mathrm{pH}$ value during storage of starter kimchi contaminated with aflatoxins

\begin{tabular}{cccccc}
\hline \multirow{2}{*}{ Samples } & \multicolumn{5}{c}{ Storage periods (week) } \\
\cline { 2 - 6 } & 0 & 2 & 4 & 6 & 8 \\
\hline $\mathrm{A}^{\mathrm{l})}$ & $5.50 \pm 0.02^{\mathrm{CD} 2)}$ & $5.38 \pm 0.01^{\mathrm{CC}}$ & $4.42 \pm 0.02^{\mathrm{BB}}$ & $4.12 \pm 0.03^{\mathrm{aA}}$ & $4.14 \pm 0.02^{\mathrm{bA}}$ \\
$\mathrm{B}$ & $5.43 \pm 0.02^{\mathrm{bD}}$ & $5.46 \pm 0.01^{\mathrm{dE}}$ & $4.37 \pm 0.02^{\mathrm{aC}}$ & $4.16 \pm 0.02^{\mathrm{bB}}$ & $4.10 \pm 0.01^{\mathrm{bA}}$ \\
$\mathrm{C}$ & $5.46 \pm 0.03^{\mathrm{bE}}$ & $5.42 \pm 0.01^{\mathrm{CD}}$ & $4.37 \pm 0.01^{\mathrm{aC}}$ & $4.10 \pm 0.02^{\mathrm{aB}}$ & $4.06 \pm 0.03^{\mathrm{aA}}$ \\
$\mathrm{D}$ & $5.37 \pm 0.02^{\mathrm{aD}}$ & $5.35 \pm 0.02^{\mathrm{aD}}$ & $4.40 \pm 0.02^{\mathrm{bC}}$ & $4.18 \pm 0.02^{\mathrm{bB}}$ & $4.12 \pm 0.01^{\mathrm{bA}}$ \\
\hline${ }^{1)} \mathrm{A}$, Control; B, Kimchi contaminated with aflatoxins (AFs); C, Kimchi contaminated \\
with aflatoxins+inoculated Lac. plantarum (AFs+LP); D, Kimchi contaminated with \\
aflatoxins+inoculated Leu. mesenteriods (AFs+LM). \\
2) Any means in the same column (a-d) or row (A-E) followed by different letters \\
are significantly (p<0.05) different by Duncan's multiple range test.
\end{tabular}

를 측정하여 Table 4에 나타내었다. 김치의 초기 산도는 0.46 0.55\% 수준으로 나타나 시료 중 대조구에서 $0.46 \%$ 로 가장 낮게 나타났으며, 모든 저장 기간에 걸쳐 다른 시료에 비해 대조구의 산도가 비교적 낮게 나타나 유의적인 차이를 보였다. 모든 시료에서 산도가 급격하게 증가한 시기는 저 장 4 주 6 주차로 이는 $\mathrm{pH}$ 의 급감한 변화 시기와 일치하며 김치의 발효가 진행됨에 따라 유기산이 생성되어 $\mathrm{pH}$ 는 감 소된 반면 산도는 증가한 것으로 판단된다. 이러한 김치의 산도변화는 발효 중 젖산균이 원재료나 양념 중의 당류를 이용하여 생성된 유기산에 의한 것으로 lactic acid가 가장 많고 acetic acid와 succinic acid, malic acid 등은 생성량이 적으며, 김치의 산도 변화에 젖산이 가장 크게 작용하는 것으로 알려져 있다(36,37). 또한 김치의 산도는 저장기간 이 증가할수록 증가하여 저장 4 주차에 $1 \%$ 에 가까운 값을 나타내었다. 일반적으로 김치의 최적산도는 $0.40 \sim 0.75 \%$ 이 며, $0.75 ~ 1.0 \%$ 는 숙성의 최종 단계이고 $1.0 \%$ 가 넘으면 섭취 하기 힘든 것으로 보고되고 있는 데(38), 본 연구에서는 저장 6주에 김치 숙성의 최종단계에 도달한 것을 확인할 수 있었다. 시료에 따라 $\mathrm{AFs}+\mathrm{LP}$ 에서는 모든 저장기간에 걸쳐 다른 시료에 비해 산도가 높게 나타나 유의적인 차이

Table 4. Changes in the titratable acidity during storage of starter kimchi contaminated with aflatoxins

(Unit: \%)

\begin{tabular}{cccccc}
\hline \multirow{2}{*}{ Samples } & \multicolumn{5}{c}{ Storage periods (week) } \\
\cline { 2 - 6 } & 0 & 2 & 4 & 6 & 8 \\
\hline $\mathrm{A}^{\mathrm{1})}$ & $0.46 \pm 0.01^{\mathrm{a} A 2)}$ & $0.63 \pm 0.02^{\mathrm{aB}}$ & $0.94 \pm 0.01^{\mathrm{abC}}$ & $0.94 \pm 0.01^{\mathrm{aC}}$ & $1.16 \pm 0.06^{\mathrm{aD}}$ \\
$\mathrm{B}$ & $0.53 \pm 0.01^{\mathrm{bCA}}$ & $0.82 \pm 0.02^{\mathrm{bB}}$ & $0.93 \pm 0.02^{\mathrm{aC}}$ & $0.93 \pm 00.3^{\mathrm{aC}}$ & $1.16 \pm 0.02^{\mathrm{aD}}$ \\
$\mathrm{C}$ & $0.55 \pm 0.01^{\mathrm{CA}}$ & $0.80 \pm 0.02^{\mathrm{bB}}$ & $0.97 \pm 0.01^{\mathrm{bC}}$ & $1.07 \pm 0.03^{\mathrm{CD}}$ & $1.27 \pm 0.01^{\mathrm{bE}}$ \\
$\mathrm{D}$ & $0.52 \pm 0.01^{\mathrm{bA}}$ & $0.79 \pm 0.02^{\mathrm{bB}}$ & $0.91 \pm 0.02^{\mathrm{aC}}$ & $1.01 \pm 0.01^{\mathrm{bD}}$ & $1.20 \pm 0.02^{\mathrm{aE}}$ \\
\hline
\end{tabular}

${ }^{1)} \mathrm{A}$ Control; B, Kimchi contaminated with aflatoxins (AFs); C, Kimchi contaminated with aflatoxins+inoculated Lac. plantarum (AFs+LP); D, Kimchi contaminated with aflatoxinstinoculated Leu. mesenteriods $(\mathrm{AFs}+\mathrm{LM})$.

${ }^{2)}$ Any means in the same column (a-d) or row (A-E) followed by different letters are significantly $(\mathrm{p}<0.05)$ different by Duncan's multiple range test.
를 보였다(p<0.05). 이는 So 등(32)의 연구에서 Lactobacillus 속을 첨가한 김치들이 스타터를 비첨가한 김치보다 더 낮은 산도를 나타내는 결과와 다른 경향을 보였다.

\section{염 도}

아플라톡신 오염 및 젖산균첨가에 따른 김치의 염도를 저장기간 별로 분석하여 그 변화를 Table 5 에 나타내었다. 아플라톡신 오염 및 젖산균첨가 처리에 따른 김치의 염도는 김장 직 후 초기 염도가 대조구에서 $2.18 \%, \mathrm{AFs}$ 오염구에서 $2.21 \%, \mathrm{AFs}+\mathrm{LP}$ 에서 $2.26 \%, \mathrm{AFs}+\mathrm{LM}$ 에서 $2.24 \%$ 로 확인되 었으며, 평균적으로 약 $2.22 \%$ 의 염도를 나타내었다. 저장기 간에 걸쳐 전반적으로 대조구에 비해 다른 시험구에서 미비 한 수준으로 염도가 높게 나타났으나 뚜렷한 차이는 나타나 지 않았다. 일반적으로 알려진 시판김치의 염도는 약 $2.38 \%$ 로 알려져 있는데(39), 이는 본 연구에서 제조한 김치의 염도와 거의 일치하는 것으로 나타났다.

발효가 진행됨에 따라 모든 시료에서 약 2.30 2.40\% 내 외의 염도를 유지하며 숙성기간 중 큰 변화는 나타나지 않았다. 이와 같이 김치의 염도 변화가 비교적 적은 이유는 발효초기에 수분함량이 높은 배추의 조직 내로 소금이 확산 되어 탈수와 침투를 반복하기 때문이며 발효 숙성이 진행되 면서 이러한 현상을 반복하면서 배추 조직 사이에 소금 농도의 평형이 이루어졌기 때문으로 여겨진다(40).

Table 5. Changes in the salinity during storage of starter kimchi contaminated with aflatoxins

(Unit: \%)

\begin{tabular}{cccccc}
\hline \multirow{2}{*}{ Samples } & \multicolumn{5}{c}{ Storage periods (week) } \\
\cline { 2 - 6 } & 0 & 2 & 4 & 6 & 8 \\
\hline $\mathrm{A}^{\mathrm{1})}$ & $2.18 \pm 0.06^{\mathrm{nAA} 2}$ & $2.31 \pm 0.03^{\mathrm{aB}}$ & $2.39 \pm 0.03^{\mathrm{bcB}}$ & $2.30 \pm 0.03^{\mathrm{nBB}}$ & $2.18 \pm 0.05^{\mathrm{aA}}$ \\
$\mathrm{B}$ & $2.21 \pm 0.04^{\mathrm{A}}$ & $2.41 \pm 0.02^{\mathrm{bC}}$ & $2.31 \pm 0.02^{\mathrm{aB}}$ & $2.25 \pm 0.08^{\mathrm{AB}}$ & $2.24 \pm 0.05^{\mathrm{AB}}$ \\
$\mathrm{C}$ & $2.26 \pm 0.01^{\mathrm{A}}$ & $2.48 \pm 0.04^{\mathrm{CD}}$ & $2.41 \pm 0.02^{\mathrm{CC}}$ & $2.27 \pm 0.02^{\mathrm{AB}}$ & $2.32 \pm 0.02^{\mathrm{bB}}$ \\
$D$ & $2.24 \pm 0.02^{\mathrm{A}}$ & $2.37 \pm 0.05^{\mathrm{abB}}$ & $2.35 \pm 0.02^{\mathrm{abB}}$ & $2.26 \pm 0.02^{\mathrm{A}}$ & $2.38 \pm 0.01^{\mathrm{bB}}$ \\
\hline
\end{tabular}

${ }^{1)} \mathrm{A}$, Control; B, Kimchi contaminated with aflatoxins (AFs); C, Kimchi contaminated with aflatoxins+inoculated Lac. plantarum $(\mathrm{AFs}+\mathrm{LP}) ; \mathrm{D}$, Kimchi contaminated with aflatoxinstinoculated Leu. mesenteriods (AFs+LM).

${ }^{2)}$ Any means in the same column (a-d) or row (A-E) followed by different letters are significantly $(p<0.05)$ different by Duncan's multiple range test

\section{미생물학적 특성}

김치는 채소류를 주재료로 하여 야생의 미생물에 의해 발효되는 자연발효식품으로 김치 발효의 특성은 단계성을 지닌다. 이러한 각 단계별 미생물학적 특성은 김치의 품질 에 매우 중요한 영향을 주기 때문에 김치의 처리나 저장기 간에 따른 균수의 변화를 살펴보는 것은 매우 중요하다고 할 수 있다(41). 아플라톡신 오염 및 젖산균 첨가에 따른 김치의 일반세균수는 담금 직 후 대조구에서 $5.73 \mathrm{log}$ $\mathrm{CFU} / \mathrm{g}, \mathrm{AFs}$ 오염구에서 $5.55 \log \mathrm{CFU} / \mathrm{g}, \mathrm{AFs}+\mathrm{LP}$ 에서 7.63 
$\log \mathrm{CFU} / \mathrm{g}, \mathrm{AFs}+\mathrm{LM}$ 에서 $7.48 \log \mathrm{CFU} / \mathrm{g}$ 수준으로 검출되 었다(Fig. 1), 특히 $\mathrm{AFs}+\mathrm{LP}$ 와 $\mathrm{AFs}+\mathrm{LM}$ 에서는 젖산균 첨가 에 따라 다른 시료에 비해 약 $2 \log \mathrm{CFU} / \mathrm{g}$ 정도의 높은 균수가 검출되었다. 발효가 진행됨에 따라 일반세균수는 서서히 증가하였고, 대조구 및 $\mathrm{AFs}$ 오염구, $\mathrm{AFs}+\mathrm{LM}$ 의 경 우 저장 4주차에 최대 수치에 도달한 반면 $\mathrm{AFs}+\mathrm{LP}$ 에서는 제조 직후 가장 높은 균수가 검출되었다. 시료에 따라 대조 구 및 $\mathrm{AFs}$ 오염구는 약 $7 \log \mathrm{CFU} / \mathrm{g}$ 수준의 최대치를 나타낸 반면 젖산균 첨가구인 $\mathrm{AFs}+\mathrm{LP}$ 와 $\mathrm{AFs}+\mathrm{LM}$ 에서는 각각 $7.63,8.40 \log \mathrm{CFU} / \mathrm{g}$ 수준으로 최대 균수가 검출되었다. 아플라톡신 오염에 따른 일반세균수의 차이는 발견되지 않았으며, 저장 6주 이후에는 모든 시료에서 약 $7 \log \mathrm{CFU} / \mathrm{g}$ 수준의 균수를 유지하였다.

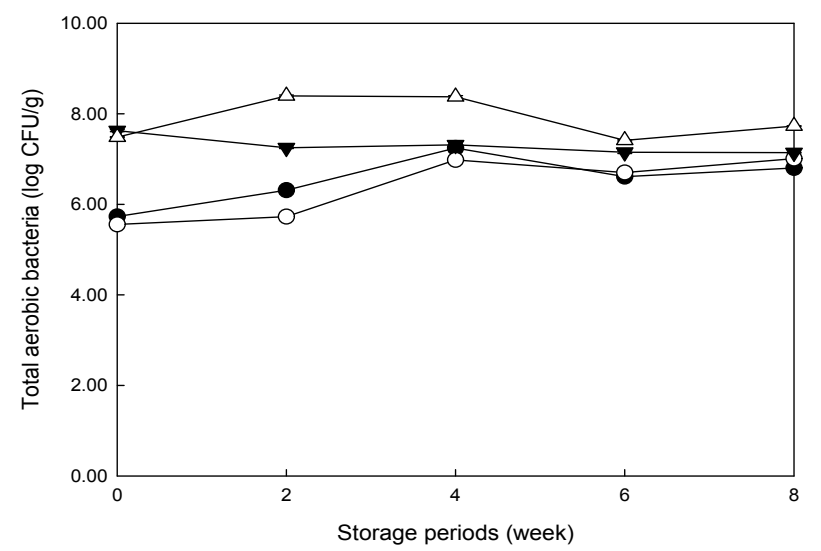

Fig. 1. Changes in the number of total aerobic bacteria during storage of starter kimchi contaminated with aflatoxins.

- Control; $\bigcirc$, Kimchi contaminated with aflatoxins (AFs); $\nabla$, Kimchi contaminated with aflatoxins+inoculated Lac. plantarum (AFs $+\mathrm{LP}) ; \triangle$, Kimchi contaminated with aflatoxinstinoculated Leu. mesenteriods $(\mathrm{AFs}+\mathrm{LM})$.

김치는 발효가 진행됨에 따라 더 많은 젖산이 생성되면 서 젖산균 자체도 자기가 생성한 젖산에 의해서 증식이 억제되거나 사멸되는 과정을 거치게 된다. 더 이상 젖산균 이 활동하지 못하게 되면 표면에서부터 젖산을 이용하는 산막효모(film yeast) 등 다양한 미생물이 증식하면서 김치 의 변질 및 변패가 일어난다고 알려져 있다(42). 아플라톡신 오염 및 젖산균 첨가에 따른 김치의 젖산균수 변화는 일반 세균수와 비슷한 경향을 나타내었다(Fig. 2). 담금 직후 김 치의 젖산균수는 5.51 7.68 $\log \mathrm{CFU} / \mathrm{g}$ 수준으로 $\mathrm{AFs}$ 오염구 에서 가장 적은 균수를 나타내었고, $\mathrm{AFs}+\mathrm{LP}$ 에서 가장 많은 균수가 검출되었다. 저장기간이 경과함에 따라 젖산균수는 대조구 및 $\mathrm{AFs}$ 오염구에서 저장 4주차에 가장 높은 균수가 검출되었으며, 젖산균첨가구인 $\mathrm{AFs}+\mathrm{LP}, \mathrm{AFs}+\mathrm{LM}$ 에서는 각각 저장 8 주 및 저장 2 주차에 높은 균수를 나타내 다른 시험구와 상이한 경향을 보였다. 젖산균 첨가구의 경우 발 효초기부터 젖산균의 수가 다른 시료에 비해 약 $2 \log \mathrm{CFU} / \mathrm{g}$ 정도 높게 검출되며 저장기간에 따라 완만한 변화를 보이는
반면, 대조구 및 $\mathrm{AFs}$ 오염구의 경우 저장기간에 따라 급격 한 변화를 나타내었으며, 이는 다른 연구 $(24,43)$ 결과와 일 치하는 것으로 나타났다. Mheen과 Kwon(23)의 연구에 의 하면 일반적으로 김치에 관여하는 젖산균 중 발효 초기 Leconostoc속이 김치를 숙성시켜 풍미를 향상시키고, 적숙 기 이후에는 Lactobacillus속의 젓산균이 주로 관여하여 김 치의 산패에 관여한다고 보고하였다.

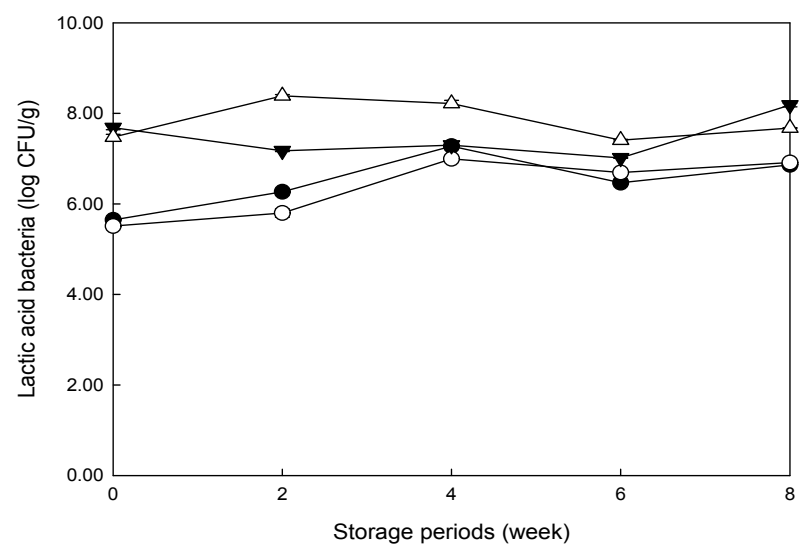

Fig. 2. Changes in the number of lactic acid bacteria during storage of starter kimchi contaminated with aflatoxins.

. Control; $\bigcirc$, Kimchi contaminated with aflatoxins (AFs); $\boldsymbol{\nabla}$, Kimchi contaminated with aflatoxins+inoculated Lac. plantarum $(\mathrm{AFs}+\mathrm{LP}) ; \triangle$, Kimchi contaminated with aflatoxinstinoculated Leu. mesenteriods (AFs+LM).

아플라톡신 오염 및 젖산균 첨가에 따른 김치의 효모 및 곰팡이 수는 김치제조 직후 대조구에서만 $2.59 \mathrm{log}$ $\mathrm{CFU} / \mathrm{g}$ 가 검출된 반면 다른 시료에서는 모두 불검출되었다 (Fig. 3). 그러나 저장 2주 이후 다른 시료에서도 모두 효모 및 곰팡이가 발생하여 대조구 및 $\mathrm{AFs}$ 오염구에서 약 $2 \log$ $\mathrm{CFU} / \mathrm{g}$ 수준의 효모 및 곰팡이수가 검출되었으며, $\mathrm{AFs}$ 오염 및 젖산균 첨가구에서 약 $1 \log \mathrm{CFU} / \mathrm{g}$ 수준의 효모 및 곰팡

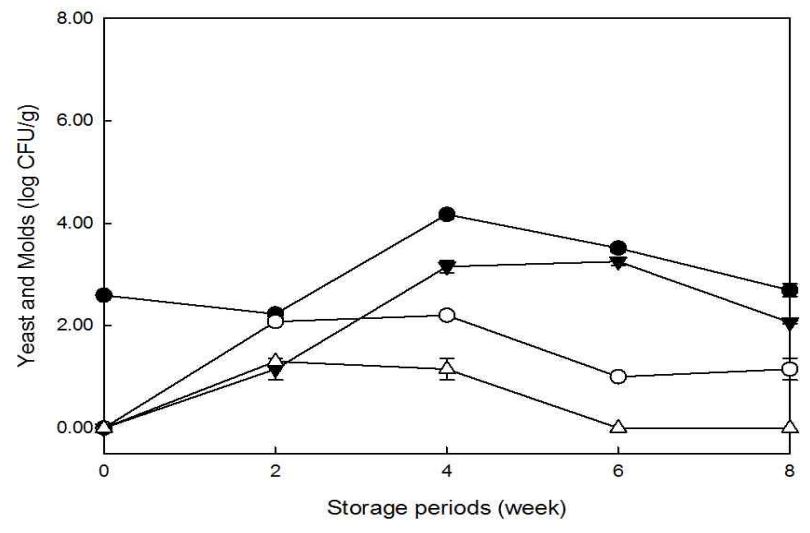

Fig. 3. Changes in number of yeast and molds during storage of starter kimchi contaminated with aflatoxins.

, Control; $\bigcirc$, Kimchi contaminated with aflatoxins (AFs); $\boldsymbol{\nabla}$, Kimchi contaminated with aflatoxins+inoculated Lac. plantarum (AFs $+\mathrm{LP}) ; \triangle$, Kimchi contaminated with aflatoxins+inoculated Leu. mesenteriods (AFs+LM). 
이수가 검출되었다. 저장기간이 경과함에 따라 효모 및 곰 팡이수는 점차 감소하는 경향을 나타내었으며, 대조구 및 $\mathrm{AFs}$ 오염구에서 저장 4주차에 최대 균수를 나타내었다. 한편 젖산균 첨가구에서 서로 상이한 경향을 나타내며 $\mathrm{AFs}+\mathrm{LP}$ 에서는 저장 6주차에 $3.25 \log \mathrm{CFU} / \mathrm{g}$ 로 최대치가 검출되고 저장 8 주차까지 효모 및 곰팡이수가 검출되었지 만, $\mathrm{AFs}+\mathrm{LM}$ 에서는 저장 2 주차에 $1.30 \log \mathrm{CFU} / \mathrm{g}$ 수준의 균주가 가장 높은 최대치로 검출되고, 저장 4 주차 이후 불검 출되었다. 일반적으로 김치에 존재하는 효모는 발효 시 알 코올 형성과 김치에 독특한 풍미를 부여하지만, 김치가 시 어지는 발효 말기에는 이취(군덕내)를 형성하여 김치에 산 막을 발생시키고, polygalacturonase와 같은 펙틴분해효소 를 생성하여 김치의 연부현상을 일으키는 것으로 알려져 있다(44-46).

Fig. 4는 아플라톡신 오염 및 젖산균 첨가에 따른 김치의 저장 중 대장균 및 대장균군의 변화를 나타낸 것이다. 제조 직후 김치의 대장균군의 수는 약 2.28 2.73 log CFU/g 수준 으로 검출된 반면 대장균은 모든 시료에서 불검출되었다. 저장기간에 따라 대장균군의 수는 대조구에서 저장 2 주차 에 가장 높은 최대치가 검출되었고, 다른 시료에서는 저장 0 주차에 최대치를 나타내며 이후 점차 감소한 뒤 저장 4 주 차에는 모두 불검출되었다. 또한 대조구도 저장 4 주차에 $1.39 \mathrm{CFU} / \mathrm{g}$ 수준의 대장균군이 검출되었으나 이후 모두 불검출되었다. 김치의 발효과정에서 미생물의 변화를 추적 한 Shin 등(47)의 연구에서는 김치의 발효초기에 병원성균 주가 검출되나 발효시간이 경과함에 따라 병원균은 검출되 지 않고 젖산균이 검출되었다고 보고하였다. 이러한 결과 는 본 연구 결과와 일치하였으며 저장기간이 증가함에 따라 대장균군의 수가 불검출 된 것은 젖산균첨가에 따라 김치에 서 젖산균의 증식이 우세하여 병원성균주인 대장균군이 사멸한 것으로 생각된다.

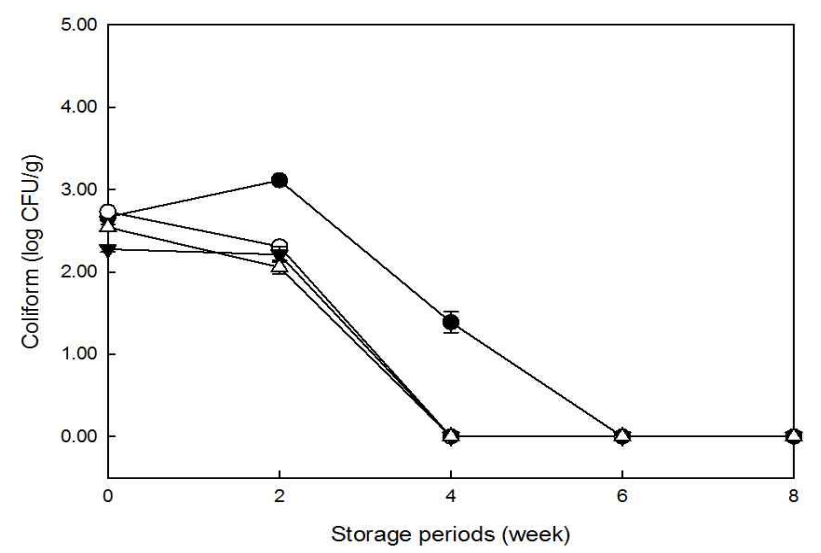

Fig. 4. Changes in number of coliforms during storage of starter kimchi contaminated with aflatoxins.

- Control; $\bigcirc$, Kimchi contaminated with aflatoxins (AFs); $\nabla$, Kimchi contaminated with aflatoxins+inoculated Lac. plantarum (AFs+LP); $\triangle$, Kimchi contaminated with aflatoxins+inoculated Leu. mesenteriods (AFs+LM).

\section{아플라톡신 생성균 및 총 아플라톡신 함량}

아플라톡신 생성균으로 알려진 Aspergillus flavus와 Aspergillus parasiticus의 존재 유무를 확인하기 위해 본 연 구에서 김치 제조 시 사용된 부재료의 아플라톡신 생성균주 확인시험을 실시하였으나 모두 불검출되어 음성으로 나타 났다(data not shown).

아플라톡신 오염 및 젖산균을 첨가한 김치의 아플라톡신 함량의 변화는 Table 6에 나타내었다. 김치의 아플라톡신 오염 농도는 총 아플라톡신에 대한 국내 규제기준이 아닌 가장 독성이 강한 아플라톡신 $\mathrm{B}_{1}$ 에 대한 기준인 $10 \mu \mathrm{g} / \mathrm{kg}$ 로 설정하여, 아플라톡신 $\mathrm{B}_{1}, \mathrm{~B}_{2}, \mathrm{G}_{1}, \mathrm{G}_{2}$ 를 각각 $10 \mu \mathrm{g} / \mathrm{kg}$ 의 농도가 되도록 김치에 오염시켰다. 따라서 총 아플라톡신 오염 농도는 약 $40 \mu \mathrm{g} / \mathrm{kg}$ 수준이었으나 본 연구에서는 아플 라톡신의 회수율이 시료별로 다르게 나타나 AFs 오염구에 서 $68.02 \%, \mathrm{AFs}+\mathrm{LP}$ 에서 $76.42 \%, \mathrm{AFs}+\mathrm{LM}$ 에서 $83.15 \%$ 로 젓산균을 첨가한 시험구에서 더 높은 회수율을 나타냈다. 특히 $\mathrm{AFs}+\mathrm{LM}$ 에서는 다른 시료에 비해 높은 회수율을 나타 내 초기 농도가 높게 검출되었지만 저장기간에 따른 감소는 가장 크게 나타났다. 일반적으로 알려진 아플라톡신의 회 수율은 유통 건고추 및 고춧가루에서 아플라톡신 B1 표준 품을 $1 \mu \mathrm{g} / \mathrm{kg}, 5 \mu \mathrm{g} / \mathrm{kg}$ 오염시켰을 때 82.2 86.1\%라고 보고 되었으며, 고춧가루에서 아플라톡신 혼합표준용액의 농도 가 $5 \mu \mathrm{g} / \mathrm{g}$ 인 것을 오염시켰을 때 아플라톡신 $\mathrm{B}_{1}, \mathrm{~B}_{2}, \mathrm{G}_{1}$, $\mathrm{G}_{2}$ 에 대하여 각각 $85.3,81.3,94.6,75.8 \%$ 로 보고되었다 $(5,48)$.

아플라톡신 $\mathrm{B}_{1}$ 은 저장 0 주차에 $6.20 \sim 7.28 \mu \mathrm{g} / \mathrm{kg}$ 수준으로 검출되었으며, 아플라톡신 $\mathrm{B}_{2}$ 는 $8.20 ~ 9.65 \mu \mathrm{g} / \mathrm{kg}$, 아플라톡 신 $\mathrm{G}_{1}$ 의 경우 $6.84 \sim 8.81 \mu \mathrm{g} / \mathrm{kg}$, 아플라톡신 $\mathrm{G}_{2}$ 는 5.96 7.52 $\mu \mathrm{g} / \mathrm{kg}$ 로 검출되었다. 아플라톡신 함량은 저장기간 및 시료 에 따른 뚜렷한 경향은 나타나지 않았으나 전반적으로 저장 6 주 및 8 주차에 가장 낮은 함량이 검출되었다. 총 아플라톡 신 함량의 경우, $\mathrm{AFs}$ 오염구에서 저장 6주차에 가장 낮은 함량이 검출된 반면, 젖산균을 첨가한 $\mathrm{AFs}+\mathrm{LP}$ 및 $\mathrm{AFs}+\mathrm{LM}$ 에서는 저장 4주차에 가장 낮은 함량이 검출되었다. 초기 오염농도 대비 저장 8주 후 아플라톡신 오염 및 젖산균을 첨가한 김치의 총 아플라톡신 평균 감소율은 $\mathrm{AFs}$ 에서 $8.39 \%, \mathrm{AFs}+\mathrm{LP}$ 에서 $25.16 \%, \mathrm{AFs}+\mathrm{LM}$ 에서 $27.86 \%$ 로 나타 나 저장기간동안 젖산균을 첨가한 시료에서 감소율이 더 크게 나타났다. Zinedine 등(28)과 Haskard 등(49)의 연구에 서는 Leuconostoc속이 아플라톡신 B1에 약 $2.15 \%$ 결합한 반면 Lactobacillus속에서는 $29.9 \%$ 결합하는 것으로 나타났 으나, 본 연구에서는 Leu. mesenteriods를 접종한 시료 $(\mathrm{AFs}+\mathrm{LM})$ 에서 아플라톡신 감소율이 높게 나타났다. 이는 아플라톡신 $\mathrm{B}_{1}, \mathrm{~B}_{2}, \mathrm{G}_{1}, \mathrm{G}_{2}$ 가 아닌 아플라톡신 $\mathrm{B}_{1}$ 에 대한 단독 비교분석만 이루어졌기 때문에 본 연구결과와 상이한 것으로 생각된다.

아플라톡신은 젖산균의 세포벽이나 세포벽을 구성하는 
Table 6. Changes in the content of aflatoxins during storage of starter kimchi contaminated with aflatoxins

(Unit: $\mu \mathrm{g} / \mathrm{kg}$ )

\begin{tabular}{|c|c|c|c|c|c|c|}
\hline \multirow{2}{*}{ Aflatoxins } & \multirow{2}{*}{ Samples } & \multicolumn{5}{|c|}{ Storage periods (week) } \\
\hline & & 0 & 2 & 4 & 6 & 8 \\
\hline \multirow{4}{*}{ B1 } & $A^{1)}$ & $\mathrm{ND}^{2)}$ & $\mathrm{ND}$ & $\mathrm{ND}$ & $\mathrm{ND}$ & $\mathrm{ND}$ \\
\hline & B & $6.20 \pm 0.01^{\mathrm{aC} 3)}$ & $6.60 \pm 0.02^{\mathrm{cD}}$ & $5.68 \pm 0.01^{1 B}$ & $5.28 \pm 0.02^{\mathrm{bA}}$ & $6.16 \pm 0.01^{\mathrm{aC}}$ \\
\hline & $\mathrm{C}$ & $6.86 \pm 0.01^{\mathrm{bD}}$ & $5.59 \pm 0.04^{\mathrm{bC}}$ & $5.07 \pm 0.00^{\mathrm{aB}}$ & $5.00 \pm 0.01^{\mathrm{aA}}$ & $6.90 \pm 0.02^{\mathrm{bD}}$ \\
\hline & $\mathrm{D}$ & $7.28 \pm 0.01^{\mathrm{cE}}$ & $5.29 \pm 0.02^{\mathrm{aA}}$ & $5.65 \pm 0.00^{\mathrm{bB}}$ & $5.87 \pm 0.00^{\mathrm{CC}}$ & $6.19 \pm 0.00^{\mathrm{aD}}$ \\
\hline \multirow{4}{*}{ B2 } & A & $\mathrm{ND}$ & ND & $\mathrm{ND}$ & $\mathrm{ND}$ & $\mathrm{ND}$ \\
\hline & B & $8.20 \pm 0.01^{\mathrm{aD}}$ & $8.86 \pm 0.01^{\mathrm{bE}}$ & $7.19 \pm 0.01^{\mathrm{bC}}$ & $7.05 \pm 0.01^{\mathrm{bB}}$ & $7.01 \pm 0.01^{\mathrm{aA}}$ \\
\hline & $\mathrm{C}$ & $9.19 \pm 0.02^{\mathrm{bE}}$ & $7.54 \pm 0.03^{\mathrm{aC}}$ & $6.37 \pm 0.02^{\mathrm{aA}}$ & $6.96 \pm 0.03^{\mathrm{aB}}$ & $7.72 \pm 0.02^{\mathrm{bD}}$ \\
\hline & $\mathrm{D}$ & $9.65 \pm 0.01^{\mathrm{cE}}$ & $7.54 \pm 0.03^{\mathrm{aC}}$ & $7.25 \pm 0.01^{\mathrm{CB}}$ & $8.18 \pm 0.03^{\mathrm{CD}}$ & $7.04 \pm 0.01^{\mathrm{aA}}$ \\
\hline \multirow{4}{*}{ G1 } & A & $\mathrm{ND}$ & $\mathrm{ND}$ & $\mathrm{ND}$ & $\mathrm{ND}$ & $\mathrm{ND}$ \\
\hline & B & $6.84 \pm 0.00^{\mathrm{aD}}$ & $7.28 \pm 0.05^{\mathrm{cE}}$ & $5.83 \pm 0.01^{\mathrm{CB}}$ & $5.17 \pm 0.03^{\mathrm{bA}}$ & $6.69 \pm 0.01^{2 \mathrm{C}}$ \\
\hline & $\mathrm{C}$ & $7.91 \pm 0.04^{6 E}$ & $5.35 \pm 0.06^{\mathrm{aC}}$ & $5.13 \pm 0.02^{2 \mathrm{~B}}$ & $5.02 \pm 0.01^{\mathrm{aA}}$ & $7.46 \pm 0.01^{b D}$ \\
\hline & D & $8.81 \pm 0.02^{\mathrm{CD}}$ & $5.90 \pm 0.02^{6 \mathrm{~B}}$ & $5.52 \pm 0.05^{\mathrm{bA}}$ & $5.92 \pm 0.02^{\mathrm{cB}}$ & $6.59 \pm 0.08^{\mathrm{aC}}$ \\
\hline \multirow{4}{*}{$\mathrm{G} 2$} & A & $\mathrm{ND}$ & $\mathrm{ND}$ & $\mathrm{ND}$ & $\mathrm{ND}$ & $\mathrm{ND}$ \\
\hline & B & $5.96 \pm 0.01^{\mathrm{aD}}$ & $6.18 \pm 0.03^{\mathrm{cE}}$ & $4.91 \pm 0.01^{\mathrm{cB}}$ & $4.32 \pm 0.01^{\mathrm{aA}}$ & $5.49 \pm 0.05^{\mathrm{CC}}$ \\
\hline & $\mathrm{C}$ & $6.61 \pm 0.02^{\mathrm{bE}}$ & $4.61 \pm 0.03^{\mathrm{aD}}$ & $4.32 \pm 0.02^{2 \mathrm{~B}}$ & $4.44 \pm 0.00^{\mathrm{bC}}$ & $4.02 \pm 0.02^{\mathrm{bA}}$ \\
\hline & $\mathrm{D}$ & $7.52 \pm 0.01^{\mathrm{cE}}$ & $5.29 \pm 0.03^{\mathrm{bC}}$ & $4.66 \pm 0.02^{\mathrm{bB}}$ & $5.40 \pm 0.00^{C D}$ & $3.69 \pm 0.01^{\mathrm{aA}}$ \\
\hline \multirow{4}{*}{ Total } & A & $\mathrm{ND}$ & ND & $\mathrm{ND}$ & $\mathrm{ND}$ & ND \\
\hline & B & $27.21 \pm 0.02^{\mathrm{aE}}$ & $26.90 \pm 0.06^{\mathrm{CD}}$ & $23.61 \pm 0.02^{\mathrm{cB}}$ & $21.82 \pm 0.01^{\mathrm{bA}}$ & $25.35 \pm 0.04^{\mathrm{bC}}$ \\
\hline & $\mathrm{C}$ & $30.57 \pm 0.09^{\mathrm{bE}}$ & $23.46 \pm 0.09^{\mathrm{aC}}$ & $20.90 \pm 0.02^{\mathrm{aA}}$ & $21.43 \pm 0.03^{\mathrm{aB}}$ & $26.10 \pm 0.00^{\mathrm{CD}}$ \\
\hline & D & $33.26 \pm 0.06^{\mathrm{CD}}$ & $25.30 \pm 0.10^{\mathrm{bC}}$ & $23.08 \pm 0.07^{\mathrm{bA}}$ & $25.38 \pm 0.01^{\mathrm{cC}}$ & $23.51 \pm 0.10^{\mathrm{aB}}$ \\
\hline
\end{tabular}

${ }^{1)}$ A, Control; B, Kimchi contaminated with aflatoxins (AFs); C, Kimchi contaminated with aflatoxinss+inoculated Lac. plantarum (AFs+LP); D, Kimchi contaminated with aflatoxinstinoculated Leu. mesenteriods (AFs+LM).

${ }^{2} \mathrm{ND}$, Not detected.

${ }^{3)}$ Any means in the same column (a-d) or row (A-E) followed by different letters are significantly $(\mathrm{p}<0.05)$ different by Duncan's multiple range test.

성분에 결합하여 결과적으로 아플라톡신 감소효과가 나 타나는 것으로 보고되었으며, 특히 아플라톡신 $\mathrm{B}_{1}$ 에 대해 서 젖산균의 세포벽을 구성하는 여러 구성성분은 아플라톡 신 $\mathrm{B}_{1}$ 의 결합에 관여하며 그 중 특정 성분의 분해가 아플라 톡신의 감소를 일으키는 것으로 보고되었다. 또한 젖산균 에 결합된 아플라톡신 $\mathrm{B}_{1}$ 의 효과적인 제거와 용매를 이용 한 아플라톡신 추출 시 젓산균의 생존력은 필수적인 요소가 아닌 것으로 보고되었다 $(25,26,49,50)$.

\section{요 약}

기후변화에 따라 오염도가 높아질 것으로 예상되는 곰팡 이독소 중 아플라톡신을 김치에 오염시켜 발효 및 저장 중 이화학적 및 미생물학적 품질변화를 분석하고, 김치 제 조 시 젖산균의 첨가가 아플라톡신의 함량 변화에 미치는 영향을 살펴보았다. 김치의 $\mathrm{pH}$ 는 저장기간이 증가함에 따 라 급격하게 감소한 반면 산도는 증가하는 경향을 보였으
며, 염도는 저장기간 동안 $2.30 ~ 2.40 \%$ 의 수준을 유지하였 다. 젖산균을 첨가한 김치의 일반세균수 및 젖산균수는 다 른 시료에 비해 젖산균을 접종한 시료에서 유의적으로 높게 나타났다 $(\mathrm{p}<0.05)$. 또한 김치의 저장 중 효모 및 곰팡이 수 는 약 $1 \sim 3 \log \mathrm{CFU} / \mathrm{g}$ 수준이 검출되었다. 대장균군은 대조 구에서 저장 4주차까지 검출된 반면 다른 시료에서는 저장 2 주 후 모두 불검출되었다. 아플라톡신이 오염된 김치에서 저장기간에 따라 아플라톡신이 감소하는 경향성은 확인되 지 않았으나 저장 8주 동안 아플라톡신 오염수준의 평균 감소율은 $\mathrm{AFs}$ 오염구에서 $7.1 \%, \mathrm{AFs}+\mathrm{LP}$ 에서 $21.5 \%$, $\mathrm{AFs}+\mathrm{LM}$ 에서 $24.1 \%$ 로 나타나 젖산균을 첨가한 시료에서 감소율이 더 크게 나타났다. 아플라톡신 첨가에 따른 김치 의 이화학적 및 미생물학적 품질 변화는 일반 김치와 비교 시 뚜렷한 차이가 나타나지 않았으나 젖산균을 첨가한 김치 의 경우 저장 중 일반세균 수 및 젖산균수가 높게 검출되고, 아플라톡신의 감소효과가 더 크게 나타났다. 따라서 본 연 구결과 김치에 Lactobacillus속이나 Leuconostoc속과 같은 젖산균 첨가 시 젖산균 증진 효과 및 아플라톡신에 노출 
위험도를 감소시킬 수 있는 것으로 나타났다.

\section{감사의 글}

본 연구는 농림축산식품부 고부가가치식품기술개발사 업(112083-3) 및 세계김치연구소 기관 고유사업(KE1503-3) 에 의해 수행된 결과이며, 연구비 지원에 감사드립니다.

\section{References}

1. Peers FG, Linsell CA (1977) Dietary aflatoxins and human primary liver cancer. Ann Nutr Aliment, 31, 1005-1017

2. Varga J, Frisvad JC, Samson RA (2011) Two new aflatoxin producing species, and an overview of Aspergillus section Flavi. Stud Mycol, 69, 57-80

3. Mushtaq M, Sultana B, Anwar F, Zargham Khan M, Ashrafuzzaman M (2012) Occurrence of aflatoxins in selected processed foods from Pakistan. Int J Mol Sci, 13, $8324-8337$

4. IARC (1993) IARC Monographs on the evaluation of carcinogenic risks to humans : some naturally occurring substances, food items and constituents, heterocyclic amines and mycotoxins. International Agency for Research on Cancer, Lyon, France, p 489-521

5. Jegal S, Kim JH, Joo GS, Jung SJ, Na HJ, Jo NG, Lee JM, Kim YH (2013) Survey of aflatoxin $B_{1}$ and ochratoxin A on commercial dried red pepper and red pepper powder. J Fd Hyg Safety, 28, 267-271

6. Park SY, Moon HJ, Cho SY, Lee JG, Lee HM, Song JY, Cho OS, Cho DH (2011) Monitoring of aflatoxins on commercial herbal medicines. J Fd Hyg Safety, 26, 315-32

7. Cho SY, Kang IH, Shim YH, Yang DH, Oh SW, Lee BH, Hyeon SY, Chang SY, Jeong CS, Lee YS, Kim YS, Kang SJ (2007) Contamination and detoxification of aflatoxins. Korean J Pharmacogn, 38, 205-216

8. Kang KJ, Kim HJ, Lee YG, Jung KH, Han SB, Park SH, Oh HY (2010) Administration of mycotoxins in food in Korea. J Fd Hyg Safety, 25, 281-288

9. Park JW, Yoo MS, Kuk JH, Ji YA, Lee JH (2013) Simultaneous determination and mornitoring of aflatoxin and ochratoxin A in food. J Fd Hyg Safety, 28, 75-82

10. Oh SH, Hwang IG, Kim HY, Hwang CR, Park SM, Hwang Y, Yoo SM, Kim HR, Kim HY, Lee JS, Jeong HS (2011) Quality characteristics by particle size of red pepper powders for pepper paste and kimchi. J Korean Soc Food Sci Nutr, 40, 599-605

11. Song YJ, Park SW, Chun SC, Choi MJ, Chung KC, Lee SK (2012) Efficient treatment methods for reducing Escherichia coli populations in commercially-available red pepper powder in Korea. J Korean Soc Food Sci Nutr, 41, 875-880

12. Kang YW, Cho TY, Park HR, Oh KS, Kim DS (2010) Analysis of total aflatoxins in spices and dried fruits. J Fd Hyg Safety, 25, 65-72

13. Cho SH, Lee CH, Jang MR, Son YW, Lee SM, Choi IS, Kim SH, Kim DB (2008) Aflatoxins contamination in spices and processed spice products commercialized in Korea. Food Chem, 107, 1283-1288

14. Kim KY, Nam MJ, Nam BR, Ryu HJ, Song JE (2010) Determination of total aflatoxins in foods by parallelism of ELISA and LC/MS/MS. J Env Hlth Sci., 36, 52-60

15. Miguel Hernandez Hierro J, Garcia-Villanova Rafael J, Purificacion Rodriguea Torrero, Ivania M, Toruno Fonseca (2008) Aflatoxins and ochratoxin A in red paprika for retail sale in Spain-occurrence and evaluation of a simultaneous analytical method. J Agric Food Chem, 56, 751-756

16. Erdogan A (2004) The aflatoxin contamination of some pepper types sold in Turkey. Chemosphere, 56, 321-325

17. Hilal Colak, Enver Baris Bingol, Hamparsun Hampikyan, Bulent Nazli (2006) Determination of aflatoxin contamination in red-scaled, red and black pepper by ELISA and HPLC. J Food Drug Anal, 14, 292-296

18. Salari R, Habibi Najafi MB, Boroushaki MT, Mortazavi SA, Fathi Najafi M (2012) Assessment of the microbiological quality and mycotoxin contamination of Iranian red pepper spice. J Agr Sci Tech, 14, 1511-1521

19. Makun HA, Mailafiya SC, Saidi AA, Onwuike BC, Onwubiko MU (2012) A preliminary survey of aflatoxin in fresh and dried vegetables in Minna, Nigeria. Afr J Food Sci Technol, 3, 268-272

20. Park KY (1995) The nutritional evaluation, and antimutagenic and anticancer effects of kimchi. J Korean Soc Food Nutr, 24, 169-182

21. Lee JY, Park YS, Kim YS, Shin DH (2002) Antimicrobial characteristics of metabolites of lactic acid bacteria isolated from feces of newborn baby and from dongchimi. Korean J Food Sci Technol, 34, 472-479

22. Stamer JR, Stoyla BO, Dunckel BA (1971) Growth rates and fermentation patterns of lactic acid bacteria associated with sauerkraut fermentation. J Milk Food Technol, 34, $521-525$

23. Mheen TI, Kwon TW (1984) Effect of temperature and 
salt concentration on Kimchi fermentation. Korean J Food Sci Technol 16, 443-450

24. Bong YJ, Jeong JK, Park KY (2013) Fermentation properties and increased health functionality of Kimchi by Kimchi lactic acid bacteria starters. J Korean Soc Food Sci Nutr, 42, 1717-1726

25. Oluwafemi F, Da-Silva FA (2009) Removal of aflatoxins by viable and heat-killed Lactobacillus species isolated from fermented maize. J Appl Biosci, 16, 871 - 876

26. Peltonen K, El-Nezami H, Haskard C, Ahokas J, Salminen S (2001) Aflatoxin B1 binding by dairy strains of lactic acid bacteria and bifidobacteria. J Dairy Sci, 84, 2152-2156

27. Shahin A (2007) Removal of aflatoxin B1 from contaminated liquid media by dairy lactic acid bacteria. Int J Agric Biol, 9, 71-75

28. Zinedine A, Faid M, Benlemlih M (2005) In vitro reduction of aflatoxin B1 by strains of lactic acid bacteria isolated from Moroccan sourdough bread. Int J Agric Biol, 7, 67-70

29. Ku KH, Kang KO, Kim WJ (1998) Some quality changes during fermentation of kimchi. Korean J Food Sci Technol, 20, 476-482

30. Ko YT, Baik IH (2002) Changes in $\mathrm{pH}$, sensory properties and volatile odor components of kimchi by heating. Korean J Food Sci Technol, 34, 1123-1126

31. Kim WJ, Kang KO, Kyung KH, Shin JI (1991) Addition of salts and their mixtures for improvements of storage stability of kimchi. Korean J Food Sci Technol, 23, 188-191

32. So MH, Shin MY, Kim YB (1996) Effects of psychrotrophic lactic acid bacterial starter on Kimchi fermentation. Korean J Food Sci Technol, 28, 806-813

33. Kang SS, Kim JM, Byun MW (1988) Preservation of Kimchi by ionizing radiation. Korean J Food Hygiene, 3, 225-232

34. Hwang IG, Kim HY, Hwang Y, Yoo SM, Jeong HS, Lee JS, Kim HY (2011) Effects of mashed red pepper on the quality characteristics of Kimchi. J Korean Soc Food Sci Nutr, 40, 1769-1775

35. Park SH, Lee JH (2005) The correlation of physicochemical characteristics of kimchi with sourness and overall acceptability. Korean J Food Cookery Sci, 21, 103-109

36. Bang BH, Seo JS, Jeong EJ (2008) A method for maintaining good Kimchi quality during fermentation. Korean J Food Nutr, 21, 51-55

37. Ryu JY, Lee HS, Rhe HS (1984) Changes of organic acids and volatile flavor compounds in kimchis fermented with different ingredients. Korean J Food Sci Technol,
16, 169-174

38. Shin JH, Kim RJ, Kang MJ, Kim GM, Sung NJ (2012) Quality and fermentation characteristics of garlic-added Kimchi. Korean J Food Preserv, 19, 539-546

39. Yi SH, Park SY, Jeong DH, Kim JY, Lee AJ, Shing HA, Moon JH, Lee J H, Kim SE, Ryou HJ, Om AS (2009) Survey research of homemade and commercial cabbage (Baechu) Kimchi on physicochemical quality characteristics. Korean J Food Cookery Sci, 25, 671-676

40. Seo HJ, Han SY, Choi HS, Han GJ, Park HY (2012) Quality characteristics of cabbage Kimchi by different packaging materials. Korean J Food Cookery Sci, 28, 207-214

41. Park HY, Ahn JA, Seo HJ, Choi HS (2011) Quality characteristics of small package Kimchi according to packing material and storage temperature. Korean J Food Cookery Sci, 27, 63-73

42. Kim YS, Shin DH (2008) Hygienic superiority of Kimchi. J food Hyg Safety, 23, 91-97

43. Han GJ, Choi HS, Lee SM, Lee EJ, Park SE, Park KY (2011) Addition of starters in pasteurized brined baechu cabbage increased kimchi quality and health functionality. J Korean Soc Food Sci Nutr, 40, 110-115

44. Chang HW, Kim KH, Nam YD, Roh SW, Kim MS, Jeon CO, Oh HM, Bae JW (2008) Analysis of yeast and archaeal population dynamics in kimchi using denaturing gradient gel electrophoresis. Int J Food Microbiol, 126, 159-166

45. Hung LD, Kyung KH (2006) Inhibition of yeast film formation in fermented vegetable by materials derived from garlic using cucumber pickle fermentation as a model system. Food Sci Biotechnol, 15, 469-473

46. Chang JY, Kim IC, Chang HC (2014) Effect of solar salt on Kimchi fermentation during long-term storage. Korean J Food Sci Technol, 46, 456-464

47. Shin SM, Park JY, Kim EJ, Han YS (2005) Investigation of some harmful bacteria in commercial Kimchi. Korean J Food Cookery Sci, 21, 195-200

48. Oh KS, Suh JH, Sho YS, Park SS, Chio WJ, Lee JO, Kim HY, Woo GJ (2007) Exposure assessment of total aflatoxin in foods. Korean J Food Sci Technol, 39, 25-28

49. Haskard CA, El-Nezami HS, Kankaanpa PE, Salminen S, Ahokas JT (2001) Surface binding of aflatoxin $B_{1}$ by lactic acid bacteria. Appl Environ Microbiol, 67, 3086-3091

50. Haskard C, Binnion C, Ahokas J (2000) Factors affecting the sequestration of aflatoxin by Lactobacillus rhamnosus strain GG. Chem Biol Interact, 128, 39-49 